\title{
Effect of some medicinal plants diets on the mono-sex Nile Tilapia (Oreochromis niloticus), growth performance, feed utilization and some physiological parameters
}

\author{
Hayam D. Tonsy ${ }^{1}$; Samy H. Mahmoud ${ }^{1}$; Eman H. Labib ${ }^{1}$ and \\ Mohamed A. Zaki ${ }^{2}$ \\ 1- Animal Production Research Institute, Agriculture research Center, Dokki, Giza, \\ Egypt \\ 2- Faculty of Agriculture, Alexandria University, Al-Shatby, Egypt.
}

\begin{abstract}
$\mathrm{T}$ he effects of diets supplemented with six different medical plants (fenugreek meal (FM), (Trigonella foenum-graecum); fenugreek sprouts meal (FSM); eucalyptus fresh leaves (EFL), (Eucalyptus citriodora); hot pepper meal (HPM) (Capsicum frutescens L. var. abbreviatum); thyme seeds meal (TSM) (Thymus vulgaris) and chamomile flowers meal (CFM), (Matricaria recutita L) at three levels $(0.00 ; 1.00$ and $2.00 \%)$ on the growth performance, feed utilization and whole body composition and some physiological parameters of the Nile tilapia (Oreochromis niloticus) fry were studied. Fish were reared in twenty six glass aquaria (100 L volume of water /aquarium; duplicates per treatment) with an average initial weight of $0.82 \pm 0.3 \mathrm{~g} /$ fish. Thirteen experimental diets were formulated to contain $30 \%$ crude protein and $438.09 \mathrm{Kcal}$ gross energy $/ 100 \mathrm{~g}$.

Results obtained are summerized in the following:

1-Regardless of levels, averages of growth performance and feed utilization parameters that affected with medicinal plants, the best were for FSM diets $(\mathrm{P} \leq 0.05)$ followed by a significant decreased order of FM; EFL; HPM and both TSM and CFM, respectively.

2-Regardless of medicinal plants sources, averages of growth performance and feed utilization parameters that affected with levels medicinal plants the best were $(\mathrm{P} \leq 0.05)$ for supplementation level of $1 \%$, follwed by a significant decreased order of 0.00 and $2.00 \%$ level, respectively.

3 -Concerning the interaction between medicinal plants sources and their levels $(0.00$, 1.00 and $2.00 \%)$ the highest growth performance and feed utilization values $(\mathrm{P} \leq 0.05)$ were obtained in group $1 \%$ FSM (diet No.4), while the lowest was recorded by the group $2 \%$ TSM (diet No.11).

4- About interactions between medicinal plants sources and their levels; it was observed that the lowest total plasma protein (g/dl), total plasma lipid (g/dl), Hb (g/dl), Ht (\%), AST (U/L), ALT (U/L) and uric acid concentrations (mg/dl) parameters were obtained by group $1 \%$ FSM (diet No.4), while the highest values were recorded by the $2 \%$ TSM (diet No.11).

In general, and based on the obtained results, it could be concluded that addition of $1 \%$ FSM is optimal for growth of the mono-sex Nile tilapia, O. niloticus, fingerlings without any adverse effect on fish health.
\end{abstract}

Keywords: Nile tilapia, Fenugreek, Eucalyptus, pepper, Thyme, Chamomile 


\section{INTRODUCTION}

There are a large number of feed additives available to improve fish growth performance. Some of these additives used in feed mill are chemical products especially hormones and antibiotics which may cause unfavorable side effects. World Health Organization encourages using of medicinal herbs and plants to substitute or minimize the use of chemicals through the global trend to go back to the nature.

Attempts to use the natural materials such as medicinal plants could be widely accepted as feed additives to enhance efficiency of feed utilization and animal productive performance (Mohamed et al., 2003). Using medicinal herbs in human feeding is a well-known culture thousands of years in ancient Egypt, India and China. In this concern, Harada (1990) stated that caraway has strong attractant effect depending on its concentration used.

The most recent studies showed successful use of spices and natural herbs in fish nutrition including marjoram, licorice roots, black seeds, peppermint, caraway seed, fennel seed, Marjoram, fenugreek seeds, ginger, Cresson, Alpinia and Ipeedeuanha as reported by Abd Elmonem et al. (2002); Sakr (2003); Shalaby et al., (2003); El-Dakar et al., (2004 a and b); El-Dakar (2004); Shalaby (2004); El_Dakar et al., (2007), El Dakar et al., (2008), Khalil et al. (2009), AlAbsawy (2010) and Abdelhamid (2010). A comparison between these plants is needed to determine the nutritional potential of each and its possibility to be used in the commercial fish feed industry.

The present study was conducted to evaluate the effect of six medical plants; (fenugreek (FM), (T.foenum-graecum); fenugreek sprouts (FS); Eucalyptus fresh leaves (EFL), (Eucalyptus citriodora); hot pepper meal (HPM) (Capsicum frutescens L. var. abbreviatum); thyme seeds meal (TSM) (Thymus vulgaris) and chamomile flowers meal (CFM), (Matricaria recutita L), at three levels $(0.00 ; 1.00$ and $2.00 \%$ LMP) on growth performance, feed conversion, feed utilization, whole body composition and physiological parameters of Nile tilapia (O. niloticus) mono-sex fry reared in aquarium.

\section{Experimental design}

\section{MATERIAL AND METHODS}

In a $6 \times 3$ factorial design, six different medical plants (fenugreek (FM), (Trigonella foenum-graecum); fenugreek sprouts (FS); Eucalyptus fresh leaves (EFL), (Eucalyptus citriodora); hot pepper meal (HPM) (Capsicum frutescens L. var. abbreviatum) ; thyme seeds meal (TSM) (Thymus vulgaris) and chamomile flowers meal ( CFM), (Matricaria recutita L)) at three levels each $(0.00 ; 1.00$ and $2.00 \%$ ) were tested .The experimental design included 13 treatments in replicates. The experimental design is shown in Table (1).

\section{Fish and culture facility}

This study was carried out at the Wet Fish Laboratory, Department of Animal and Fish Production, Faculty of Agriculture, Alexandria University. The 
experimental part of the present study was carried out to determine and investigate the response of Nile tilapia mono-sex (O. niloticus) fingerlings to six different medical plants (FM, FSM, EFL, HPM, TSM and CFM) at three different levels $(0.00 ; 1.00$ and $2.00 \%)$, each as feed additive on fish growth performance, feed utilization and whole body composition. Fish were placed randomly in twenty six glass aquaria with dimensions of $100 \times 40 \times 30 \mathrm{~cm}$ each and $100 \mathrm{~L}$ volume of water /aquarium; duplicates per treatment were used in this study. Fish were acclimated to the experimental system for 15 days before starting the experiments, then they were reweighed in each aquarium, and their initial weights were recorded. Each aquarium was stocked with ten fingerlings of (O. niloticus) with an average initial body weight of $0.83 \pm 0.3 \mathrm{~g} /$ fish.

Table 1: The experimental design and diets combinations.

\begin{tabular}{|c|l|}
\hline Diet No. & \multicolumn{1}{|c|}{ Feed Additives } \\
\hline 1 & without medical plants (control diet (C)) \\
\hline 2 & C + diet with 1 \% FM \\
\hline 3 & C + diet with 2 \% F M \\
\hline 4 & C +with 1 \% FSM \\
\hline 5 & C +with 2 \% FSM \\
\hline 6 & C +with 1 \% EFL \\
\hline 7 & C +with 2 \% EFL \\
\hline 8 & C +with 1 \% HPM \\
\hline 9 & C +with 2 \% HPM \\
\hline 10 & C +with 1 \% TSM \\
\hline 11 & C +with 2 \% TSM \\
\hline 12 & C +with 1 \% CFM \\
\hline 13 & C +with 2 \% CFM \\
\hline
\end{tabular}

\section{Experimental diets}

Chemical proximate analysis of feed ingredients used in the present study is presented in Table (2). Therteen experimental diets were formulated to contain $30 \%$ crude protein and almost $438.09 \mathrm{Kcal}$ gross energy $/ 100 \mathrm{~g}$.For formulation of the thirteen experimental diets the following ingredients were used: fish meal, soybean meal, wheat bran, yellow corn, fish oil, vitamin and mineral mixture, to illustrate the effect of six different medical plants (FM, FSM, EFL, HPM, TSM and CFM) at three different levels $(0.00 ; 1.00$ and $2.00 \%)$ from them on the performance, nutritional and physiological parameters of Nile tilapia ( $O$. niloticus) fry. The ingredients and the six medical plants were bought from the local market in Alexandria.

Formulation of the tested diets is presented in Table (3). Each ingredient was ground and thoroughly mixed with the other dietary ingredients, vitamins and minerals mixtures. A few drops of oil was added at the same time of mixing with warm water $\left(45^{\circ} \mathrm{C}\right)$, which was slowly added until the diets began to clump. 
Diets were processed by a California pellet mill machine and dried for $48 \mathrm{hrs}$ at $70^{\circ} \mathrm{C}$ in a drying oven. The pellet size was $0.6 \mathrm{~mm}$ in diameter and $2 \mathrm{~mm}$ in length. Fish in each aquarium were fed two times daily (six days a week) at a rate of $5 \%$ of body weight for 112 days.

Table 2: Chemical analysis (\%) of the ingredients used in the experimental diets (on DM basis).

\begin{tabular}{|c|c|c|c|c|c|c|c|}
\hline Inqredient & $\begin{array}{c}\text { Dyymatter } \\
\% \mathrm{j}\end{array}$ & Cnde protein (\%) & $\begin{array}{c}\text { Ether } \\
\text { extact } \\
(\%)\end{array}$ & $\begin{array}{c}\text { Cinde } \\
\text { fiber } \% \text { (O) }\end{array}$ & $\begin{array}{l}\text { Ash } \\
\%\end{array}$ & $\begin{array}{c}\text { HFE* } \\
\%\end{array}$ & $\begin{array}{l}\text { Gross energer** } \\
(\mathrm{Kcal} / 100 \mathrm{~g} \text { DM) }\end{array}$ \\
\hline Fi:h meal & 80.66 & 6620 & 1090 & 562 & 1728 & 0.00 & 47627 \\
\hline Sontean meal & 8.66 & 44.12 & 1.73 & 583 & 682 & 41.50 & 435.74 \\
\hline Tellew com & 8.49 & 7.49 & 4.80 & 1.40 & 2.14 & 83.17 & 42938 \\
\hline What bran & 80.00 & 14.11 & 3.71 & 11.13 & 630 & 64.75 & 38154 \\
\hline Feruzreak meal (FM) & 91.11 & 2620 & 8.10 & 4.80 & 3.12 & 5778 & 48.43 \\
\hline Feruzgelk sprott meal (FSM) & 85.16 & 27.50 & 7.12 & 531 & 2.76 & 57.31 & 46228 \\
\hline Eucalyp tis fresh leaves ( EFL) & 84.17 & 7.64 & 5.72 & 14.19 & 362 & 6880 & 360.79 \\
\hline Hot pepper meal(HFM) & 767 & 1.20 & 0.25 & 4.11 & 421 & 90.23 & 38088 \\
\hline Thyme seds meal (TSM) & 89.82 & 4.74 & 2.82 & 2.71 & 750 & 82.23 & 392.13 \\
\hline Chamorile flowers meal (CFM) & 8.11 & 20.15 & 875 & 5.43 & 587 & 59.80 & 44263 \\
\hline
\end{tabular}

* NFE $=$ Nitrogen free extract (Calculated by differences)

** GE= Gross Energy:- Gross energy was calculated using factors 5.64, 9.44 and $4.12 \mathrm{Kcal}$ per gram of protein, lipid and carbohydrate, respectively after (NRC, 1993).

Table 3: Composition and proximate analysis (\%) of experimental diets (on DM basis).

\begin{tabular}{|c|c|c|c|c|c|c|c|c|c|c|c|c|c|}
\hline \multirow[b]{2}{*}{ Items } & \multirow[t]{2}{*}{ C } & \multicolumn{2}{|c|}{ FM (\%) } & \multicolumn{2}{|c|}{ FSM (\%) } & \multicolumn{2}{|c|}{ EFL $(\%)$} & \multicolumn{2}{|c|}{ HPM $(\%)$} & \multicolumn{2}{|c|}{ TSM \% } & \multicolumn{2}{|c|}{ CFM $\%$} \\
\hline & & $\mathrm{l}$ & 2 & $\bar{l}$ & 2 & l & 2 & l & 2 & $\mathrm{l}$ & 2 & l & 2 \\
\hline 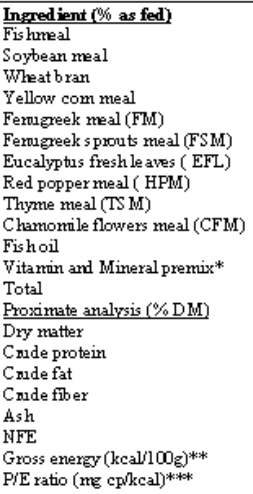 & $\begin{array}{c}15 \\
38 \\
12 \\
30 \\
- \\
- \\
- \\
- \\
- \\
- \\
3 \\
2 \\
100 \\
94.51 \\
31.39 \\
4.11 \\
4.32 \\
6.09 \\
54.15 \\
43839 \\
71.00\end{array}$ & $\begin{array}{c}15 \\
38 \\
12 \\
29 \\
1 \\
- \\
- \\
- \\
- \\
- \\
3 \\
2 \\
100 \\
94.51 \\
31.59 \\
4.14 \\
4.36 \\
6.04 \\
53.87 \\
438.66 \\
72.01\end{array}$ & $\begin{array}{c}15 \\
38 \\
12 \\
28 \\
2 \\
- \\
- \\
- \\
- \\
- \\
3 \\
2 \\
100 \\
94.52 \\
31.78 \\
4.17 \\
4.39 \\
6.05 \\
5361 \\
430.94 \\
72.40\end{array}$ & $\begin{array}{c}15 \\
38 \\
12 \\
29 \\
- \\
1 \\
- \\
- \\
- \\
- \\
3 \\
2 \\
100 \\
94.45 \\
31.39 \\
4.13 \\
4.36 \\
604 \\
54.08 \\
432.29 \\
71.62\end{array}$ & $\begin{array}{c}15 \\
38 \\
12 \\
28 \\
- \\
2 \\
- \\
- \\
- \\
- \\
3 \\
2 \\
100 \\
94.40 \\
31.38 \\
4.15 \\
4.41 \\
6.05 \\
54.01 \\
438.14 \\
71.62\end{array}$ & $\begin{array}{c}15 \\
33 \\
12 \\
20 \\
- \\
- \\
1 \\
- \\
- \\
- \\
3 \\
2 \\
100 \\
94.44 \\
31.32 \\
4.09 \\
4.35 \\
6.04 \\
54.20 \\
430.01 \\
71.51\end{array}$ & $\begin{array}{c}15 \\
38 \\
12 \\
28 \\
- \\
- \\
2 \\
- \\
- \\
- \\
3 \\
2 \\
100 \\
94.38 \\
31.25 \\
4.08 \\
4.37 \\
6.04 \\
54.26 \\
437.78 \\
71.38\end{array}$ & $\begin{array}{c}15 \\
38 \\
12 \\
29 \\
- \\
- \\
- \\
1 \\
- \\
- \\
3 \\
2 \\
100 \\
93.68 \\
31.32 \\
4.06 \\
4.35 \\
6.05 \\
54.22 \\
437.81 \\
71.54\end{array}$ & $\begin{array}{c}15 \\
38 \\
12 \\
28 \\
- \\
- \\
- \\
2 \\
- \\
- \\
3 \\
2 \\
100 \\
92.8 \\
31.35 \\
4.02 \\
437 \\
6.07 \\
54.19 \\
437.5 \\
71.66\end{array}$ & $\begin{array}{c}15 \\
38 \\
12 \\
29 \\
- \\
- \\
- \\
- \\
1 \\
- \\
3 \\
2 \\
100 \\
94.5 \\
3132 \\
4.09 \\
4.34 \\
6.09 \\
54.16 \\
437.9 \\
71.52\end{array}$ & $\begin{array}{c}15 \\
38 \\
12 \\
28 \\
- \\
- \\
- \\
- \\
2 \\
- \\
3 \\
2 \\
100 \\
945 \\
31.25 \\
4.07 \\
4.34 \\
6.14 \\
54.20 \\
437.4 \\
71.44\end{array}$ & $\begin{array}{c}15 \\
38 \\
12 \\
20 \\
- \\
- \\
- \\
- \\
- \\
1 \\
3 \\
2 \\
100 \\
94.5 \\
31.36 \\
4.15 \\
4.36 \\
6.07 \\
54.06 \\
4382 \\
71.57\end{array}$ & $\begin{array}{c}94.42 \\
31.33 \\
4.19 \\
4.40 \\
6.11 \\
5397 \\
438.1 \\
71.51\end{array}$ \\
\hline
\end{tabular}

*Each $\mathrm{Kg}$ vitamin \& mineral mixture premix contained Vitamin A, 4.8 million IU, D3, 0.8 million IU; E, 4 g; K, 0.8 g; B1, 0.4 g ; Riboflavin, 1.6 g; B6, 0.6 g, B12, 4 mg; Pantothenic acid, 4 g; Nicotinic acid, 8 g; Folic acid, 0.4 g Biotin, 20 mg , Mn, 22 g; Zn, 22 g; Fe, 12 g; Cu, 4 g; I, $0.4 \mathrm{~g}$, Selenium, $0.4 \mathrm{~g}$ and Co, $4.8 \mathrm{mg}$. ${ }^{* *} \mathrm{GE}=$ Gross Energy:- Gross energy was calculated as $5.64,9.44$ and $4.11 \mathrm{Kcal}$ per gram of protein, lipid and carbohydrate,respectively after (NRC, 1993).

**P/E ratio $=$ Protein to energy ratio $\mathrm{mg}$ crude protein/Kcal GE. 


\section{Water quality:}

Water quality parameters in the experimental glass aquaria in the experiment were determined according to the methods of APHA (1992). Ammonia and nitrite were measured at weekly intervals, while water temperatures were recorded daily in each aquaria. Also, dissolved oxygen was measured daily by oxygen meter and $\mathrm{pH}$ by $\mathrm{pH}$ meter.

\section{Measurement of growth:-}

Total weight gain, average daily gain, specific growth rate, feed conversion ratio protein and energy utilization were calculated according to Recker, (1975) and Castell and Tiews, (1980).

Total gain $(\mathrm{g} /$ fish $)=\left(\mathrm{W}_{\mathrm{T}}-\mathrm{W}_{\mathrm{I}}\right)$

Where: $\mathrm{W}_{\mathrm{T}}$ : Final weight of fish in grams and $\mathrm{W}_{\mathrm{I}}$ : Initial weight of fish in grams

Average daily gain $(\mathrm{ADG})(\mathrm{g} / \mathrm{fish} /$ day $)=$ total gain / duration period in day Specific growth rate $(\mathrm{SGR}, \% /$ day $)=100 \times\left(\ln \mathrm{W}_{\mathrm{T}}-\ln \mathrm{W}_{\mathrm{I}}\right) /$ duration period/day. Where $\ln$ is the natural log

\section{Measurement of feed and nutrient utilization:-}

Feed conversion ratio $(\mathrm{FCR})=$ dry matter intake $(\mathrm{g}) /$ total gain $(\mathrm{g})$.

Protein efficiency ratio $(\mathrm{PER})=$ total gain $(\mathrm{g}) /$ protein intake $(\mathrm{g})$.

Protein productive value $(\mathrm{PPV} \%)=\left(\mathrm{P}_{\mathrm{T}}-\mathrm{P}_{\mathrm{I}}\right) \times 100 /$ protein intake $(\mathrm{g})$.

Where: $\mathrm{P}_{\mathrm{T}}$ : Protein content in fish carcass at the end and $\mathrm{P}_{\mathrm{I}}$ : Protein content at the start.

Energy utilization $(\mathrm{EU} \%)=\left(\mathrm{E}_{\mathrm{T}}-\mathrm{EI}\right) \times 100 /$ Energy intake $(\mathrm{kcal})$.

Where: $\mathrm{E}_{\mathrm{T}}$ : Energy in fish carcass (kcal) at the end and $\mathrm{E}_{\mathrm{I}}$ : Energy in fish carcass at the start.

\section{Proximate Analysis of Diet and Fish}

The chemical analysis of ingredients, medicinal plants, diets and fish samples were analyzed according to A.O.A.C. (2000) methods for dry matter, crude protein, ether extract, crude fiber and ash. Gross energy (GE) contents of the experimental diets and fish samples were calculated by using factors of 5.65 , 9.45 and $4.12 \mathrm{kcal} / \mathrm{g}$ of protein, lipid and carbohydrates, respectively (NRC, 1993).

\section{Blood parameters determination:}

At the end of the experiment, blood samples from the fish of the different groups were collected from the caudal peduncle. Adequate amounts of whole blood were collected in small plastic vials containing heparin used for the determination of hemoglobin concentration $(\mathrm{Hb}) ;(\mathrm{g} / \mathrm{dl})$, Hematocrit $(\mathrm{Ht})$ by using commercial kits (Diamond Diagnostic, Egypt). Other blood samples were collected and then centrifuged at $3500 \mathrm{rpm}$ for $15 \mathrm{~min}$ to obtain blood plasma for determination of total protein (Gornall et al., 1949); uric acid (Schultz,1984), Total cholesterol (Ellefson and Caraway,1976, aspartate aminotransferase (AST) and alanine aminotransferase (ALT) (Varley, 1976) using a spectrophotometer (model 5010, Germany) and commercial kits. 


\section{Statistical Analysis}

Statistical analyses of growth performance parameters, feed utilization parameters and whole body composition data were done using analysis of variance of data according to Steel and Torrie (1980). Statistical analysis was applied using the SAS (1997) with factorial design including comparisons between significant means.

\section{A) Growth performance}

\section{RESULTS AND DISCUSSION}

As presented in Table (4) and Fig. (a) average of final body weight (g/fish), total weight gain (TWG) (g/fish), average daily gain (ADG) (g/fish/day) and specific growth rate (SGR \%/day) as affected with medicinal plants sources indicate that fenugreek sprouts meal (FSM) showed the highest growth performance parameters $(\mathrm{P} \leq 0.05)$ followed in a significant $(\mathrm{P} \leq 0.05)$ decreasing order by fenugreek meal (FM) and eucalyptus fresh leaves (EFL) then by hot pepper meal (HPM) and both Thyme meal (TM) and Chamomile flowers meal (CFM), respectively. These results are in accordance with those reported by Abdelhamid (2010) who showed that the diet containing Alpinia (AM) as a medicinal plant produced the best growth performance parameters compared with other different medicinal plants (Ginger (GM), Cresson (CM) and Lpecdcuanha (IM). The beneficial effect of fenugreek meal (FM) or fenugreek sprouts meal (FSM) may be due to its contents of active materials according to Dixit et al. (2005) who reported that FM or FSM have antioxidant activity.

Also, they reported that different fractions of the germinated fenugreek seeds were used to determine their antioxidant potential at different levels. So, they study reveals significant antioxidant activity in germinated fenugreek seeds which may be due partly to the presence of flavonoids and polyphenols. Billaud and Adrian (2001) observed that fenugreek seeds contain lysine and Ltryptophan rich proteins, mucilaginous fibre and ther rare chemical constituents such as saponins, coumarin, fenugreekine, nicotinic acid, sapogenins, phytic acid, scopoletin and trigonelline, which are thought to account for many of its presumed therapeutic effects. On the other hand, the lowest growth performance parameters in this study were achieved by the group of fish fed diet containing thyme seed meal (TSM).The present results disagree with the findings of Tonsy et al., (2010) they found that addition of either thyme improved the performances of low protein diets for Nile tilapia fry.

Regarless of medicinal plants sources, final body weight $(\mathrm{g} / \mathrm{fish})$, total weight gain (TWG) (g/fish), average daily gain (ADG) (g/fish/day) and specific growth rate (SGR \%/day) as affected with levels (Table 4) and Fig. (b) were found to be $49.22,52.07$ and $50.35 \mathrm{~g} /$ fish; $48.40,51.25$ and $49.51 \mathrm{~g} /$ fish; 0.44 , 0.42 and $0.44 \mathrm{~g} /$ fish/day and $3.65,3.70$ and $3.67 \%$ /day, respectively. 
Table 4: Effect of some medicinal plants (FM, FSM, EFL, HPM, TSM and CFM) at different levels $(0.00,1.00$ and $2 \%)$ as a feed additive on growth performance parameter of the Nile tilapia (O. niloticus) fry.

\begin{tabular}{|c|c|c|c|c|c|}
\hline \multirow{2}{*}{ Trustriart } & \multicolumn{2}{|c|}{ Eo dy ure ight } & \multirow{2}{*}{$\begin{array}{l}\text { Totaluwe ight } \\
\text { Gain (of ish) }\end{array}$} & \multirow{2}{*}{ 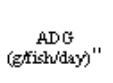 } & \multirow{2}{*}{$\begin{array}{c}\text { SGR } \\
\text { (\%idy })\end{array}$} \\
\hline & Fitial(gfich) & Firil $(g f i \leq k i)$ & & & \\
\hline \multicolumn{6}{|c|}{ Medicitalplante (MP) } \\
\hline Faropese weal (FM) & $0.82^{\circ}$ & $51.52^{b}$ & $50.70^{\mathrm{b}}$ & $0.45^{\mathrm{b}}$ & $3.69^{\mathrm{b}}$ \\
\hline Frome en sponts meal (FSM) & $0.85^{\circ}$ & $5.42^{\circ}$ & $5260^{\circ}$ & $0.47^{\mathrm{n}}$ & $3.72^{\circ}$ \\
\hline Eucabptus fiesh leaves ( EFL) & $0.83^{\mathrm{a}}$ & $5030^{\mathbf{k}}$ & $49.48^{\mathrm{r}}$ & $0.40^{\mathrm{5}}$ & $367^{\mathrm{tc}}$ \\
\hline Hotpepper meal (HF'M) & $0.83^{\circ}$ & $50.00^{\circ}$ & $4923^{5}$ & $0.44^{\mathrm{C}}$ & $366^{\mathrm{d}}$ \\
\hline Thyorm seds mal( TSlW) & $0.82^{\circ}$ & $40.52^{\mathrm{d}}$ & $47.70^{\mathrm{d}}$ & $0.43^{\mathrm{d}}$ & $3.64^{d}$ \\
\hline Chamormile fhwers meal (CFW) & $0.82^{\circ}$ & $49.43^{d}$ & $485 \mathrm{l}^{\mathrm{d}}$ & $036^{r}$ & $365^{\mathrm{W}}$ \\
\hline \multicolumn{6}{|c|}{ Lewe ls of me dicinalplates (LimP) } \\
\hline $0 \%$ & $0.82^{0}$ & $4922^{\mathrm{C}}$ & $48.40^{\mathrm{C}}$ & $0.44^{\mathrm{b}}$ & $3.65^{\mathrm{b}}$ \\
\hline $1 \%$ & $0.82^{\mathrm{D}}$ & $5207^{\circ}$ & $51.25^{\circ}$ & $0.42^{\mathrm{a}}$ & $3.70^{\circ}$ \\
\hline $2 \%$ & $0.85^{\mathrm{a}}$ & $5034^{b}$ & $49.51^{b}$ & $0.44^{\mathrm{b}}$ & $3.67^{\mathrm{b}}$ \\
\hline \multicolumn{6}{|c|}{ MIF $\times$ LMIP } \\
\hline Cortrol dit, (C) (Giet 1) & 082 & 4922 & 48.40 & 0.44 & 3.65 \\
\hline$[+d i t w i t h l \%$ FM (diut 2$)$ & 083 & 5061 & 49.79 & 0.45 & 360 \\
\hline $\mathrm{d}+\operatorname{dit} \mathrm{will} 2 \mathrm{~g}$ F M( diet 3$)$ & 082 & 54.73 & 5392 & 0.48 & 3.76 \\
\hline ¿ +wifl 1 W FSW (diet 4) & 0.83 & 57.40 & 56.58 & 0.51 & 3.79 \\
\hline $\mathrm{C}+$ will 2 \% FSW (dint 5$)$ & 083 & 565 & 5282 & 0.47 & 3.72 \\
\hline 0 +with $1 \%$ EFL $\quad($ dint 6$)$ & 084 & 51.40 & 5057 & 033 & 3.68 \\
\hline ¿+with2 \& EFL $\quad(\operatorname{diet} 7)$ & 082 & 5029 & 49.47 & 0.45 & 368 \\
\hline$[+$ +xih $1 \%$ HEM (diet 9$)$ & 083 & $5+00$ & 53.10 & 0.49 & 3.74 \\
\hline $\mathrm{C}+$ will $2 \mathrm{k}$ HPM (diet 9 ) & 084 & 4697 & 46.13 & 0.42 & 3.59 \\
\hline $\mathrm{C}+$ with $1 \%$ TSJuI (diet 10$)$ & 082 & 4887 & 4805 & 0.43 & 365 \\
\hline c +with $2 \%$ TSMI (dietl) & 083 & 47.47 & 4665 & 0.42 & 362 \\
\hline D +writl $1 \%$ FCM (diet 12$)$ & 082 & 50.14 & 4933 & 032 & 368 \\
\hline L +with $2 \%$ FChI (diet13) & 082 & 48.93 & 48.11 & 032 & 355 \\
\hline$I S D(Q=0.05)$ & $\mathrm{H} 5$ & 2.384 & 2381 & 0.019 & 0.045 \\
\hline
\end{tabular}

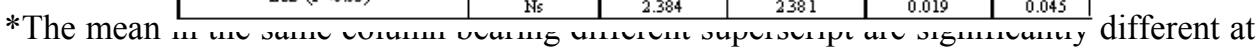
$(\mathrm{P} \leq 0.05), \mathrm{Ns}=$ not significant

$* * \mathrm{ADG}=$ Average daily gain (g/fish/day).

$* * * \mathrm{SGR}=$ Specific growth rate $(\% /$ day $)$.

The analysis of variance for medicinal plant levels (MPL) indicated that supplementation level of $1 \%$ revealed significantly $(\mathrm{P} \leq 0.05)$ the highest growth performance parameters followed in a significant $(\mathrm{P} \leq 0.05)$ decreasing order by 0.00 and $2.00 \%$ level, respectively. These results are in agreement with Abdelhamid (2010); Khalil et al. (2009). On the other side, El-Dakar et al. (2008) suggested that the highest SGR (\%/day) was recorded by fish fed $2 \%$ DBL followed by $1 \%$ and $0.5 \%$.

Concerning the interaction between medicinal plants sources and their levels $(0.00,1.00$ and $2.00 \%)$ the highest final body weight (g/fish), total weight gain $(\mathrm{TWG})(\mathrm{g} /$ fish) and specific growth rate (SGR \%/day) $(\mathrm{P} \leq 0.05)$ were obtained by group $1 \%$ FSM (diet No.4), while the lowest was recorded by group 
$2 \%$ TSM ( diet No.11). These results are in agreement with the results of AbdelWahhab et al. (2001); Abdel-Maksoud et al. (2002); Abdel-Latif et al. (2004); Abd Elmonem et al. (2002); Sakr (2003); Shalaby et al. (2003); El-Dakar et al. (2004a) and Shalaby (2004). Also, Khalafalla (2009) who reported that fish fed diets contained $1 \%$ level of dried marjoram leaves (DML), caraway seed meal (CSM), chamomile flowers meal (CFM) and fennel seed meal (FSM) were superior in growth performances of Nile tilapia fry as compared to those fed $0.5 \%$ level. On the other hand, the present results disagree with the findings of Salem, (2008) who reported that addition of $1 \%$ fenugreek seed as antimycotoxins in Nile tilapia diets decreased the growth performance parameters.

\section{B) Feed Utilization}

Table (5) and Figs. (c and d) showed the effect of medicinal plants (FM, FSM, EFL, HPM, TSM and CFM) and their levels on feed and nutrients utilization of the Nile tilapia (O. niloticus) fingerlings. These results showed that the average of feed intake between all treatments was not significantly $(\mathrm{P} \geq 0.05)$ affected with plants tested. Also, the average of feed conversion ratio (FCR) as affected with medicinal plants sources indicate that fenugreek sprouts meal (FSM) showed improved FCR parameters $(\mathrm{P} \leq 0.05)$ followed in a significant decreasing order by FM and EFL then by HPM and both TSM and CFM, respectively. These results are in accordance with those reported by Abdelhamid (2010) who showed that the diet containing Alpinia (AM) as a medicinal plant produced the best FCR parameters compared with other medicinal plant sources (Ginger (GM), Cresson (CM) and Lpecdcuanha (IM).

The average of protein efficiency ratio (PER) as affected with medicinal plants sources indicate that fenugreek sprouts meal (FSM) showed the highest PER value $(\mathrm{P} \leq 0.05)$ followed in a significant decreasing order by FM and EFL then by HPM and both TSM and CFM, respectively.

The same trend was observed in protein productive value (PPV\%) and energy utilization $(\mathrm{EU} \%)$ where the highest value $(\mathrm{P} \leq 0.05)$ were obtained by the group fish fed on FSM followed in a significant decreasing order by FM and EFL then by HPM and both TSM and CFM, respectively.

These results confirm those found previously by Abdelhamid (2010); Khalil et al. (2009); El-Dakar et al. (2008). On the other hand, the lowest feed utilization parameters in this study were achieved by the group of fish fed diet containing TSM. The present results disagree with the findings of Tonsy et al. (2010) who found that addition of thyme improved the feed utilization parameters of low protein diets for Nile tilapia fry. On the other side there were no significant differences $(\mathrm{P} \geq 0.052)$ in feed intake (FI) $(\mathrm{g} /$ fish) of Nile tilapia fed on the experimental diets, (Tables 5). 
Table 5: Effect of some medicinal plants (FM, FSM, EFL, RPM, TSM and CFM) at different levels $(0.00,1.00$ and $2 \%)$ as a feed additive on feed and nutrient utilization parameter of the Nile tilapia (O. niloticus) fry.

\begin{tabular}{|c|c|c|c|c|c|}
\hline \multirow[b]{2}{*}{ Treatment } & \multicolumn{2}{|c|}{ Feed utilization } & \multicolumn{2}{|c|}{ Froteinutilization } & \multirow{2}{*}{$\begin{array}{c}\text { Energy } \\
\text { utilization }(\%)\end{array}$} \\
\hline & 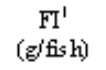 & $\mathrm{FCF}^{2}$ & $\mathrm{PER}^{3}$ & $\mathrm{PFW}^{4} \%$ & \\
\hline \multicolumn{6}{|c|}{ Mediciral plant: (MP) } \\
\hline Fenpgrek meal (FM) & $11595^{\circ}$ & $229^{\mathrm{E}}$ & $1.42^{\mathrm{b}}$ & 23.95 & $13.8^{b}$ \\
\hline Fenngresk spronts meal (FSM) & $11755^{\circ}$ & $225^{5}$ & $1.46^{\circ}$ & $24.71^{\circ}$ & $14.30^{\circ}$ \\
\hline Eucalyptas fresh leaves (EFL) & $11694^{\circ}$ & $2.36^{6}$ & 1.39 & $23.39^{\mathbf{2}}$ & $13.44^{2}$ \\
\hline Hot pepper meal (HPM) & $11832^{\circ}$ & $2.41^{\circ}$ & $1.36^{\top}$ & $22.70^{d}$ & $13.13^{d}$ \\
\hline Thyme meal (TSM) & $11773^{\circ}$ & $2.47^{\circ}$ & $1.33^{\mathrm{d}}$ & $21.89=$ & $12.73^{r}$ \\
\hline Chamomile fowers meal (CFM) & $116.73^{\circ}$ & $2.40^{\mathrm{b}}$ & $1.36^{\top}$ & $22.70^{\mathrm{d}}$ & $13.17^{d}$ \\
\hline \multicolumn{6}{|c|}{ Levels of medicimal plants (LMP) } \\
\hline $0 \%$ & $11528^{\circ}$ & $2.38^{b}$ & $1.35^{a}$ & $22.73^{\mathbf{b}}$ & $12.76^{\mathrm{T}}$ \\
\hline $1 \%$ & $11991^{\circ}$ & $235^{6}$ & $1.4 \square^{\circ}$ & $23.43^{\circ}$ & $13.84^{\circ}$ \\
\hline $2 \%$ & $119.41^{\circ}$ & $2.42^{\mathrm{a}}$ & $1.6^{\mathrm{b}}$ & $22.62^{\mathrm{b}}$ & $13.2 \delta^{\mathrm{b}}$ \\
\hline \multicolumn{6}{|c|}{$M P \times \operatorname{LMP}$} \\
\hline cortrol diet, (C) (diet l) & 115.28 & 2.38 & 1.38 & 22.73 & 12.76 \\
\hline $\mathrm{C}+$ diet with $1 \%$ FM (diet 2$)$ & 118.00 & 2.37 & 1.36 & 22.93 & 13.66 \\
\hline $\mathrm{C}+$ diet with $2 \% \mathrm{~F} \mathrm{M}($ diet 3$)$ & 117.57 & 2.18 & 1.49 & 25.31 & 14.95 \\
\hline C +with $1 \%$ FSM (diet 4) & 120.57 & 2.16 & 1.54 & 26.10 & 15.32 \\
\hline $\mathrm{C}+$ with $2 \% \mathrm{FSM}$ (diet 5 & 119.82 & 2.27 & 1.45 & 24.42 & 14.34 \\
\hline $\mathrm{C}+$ with $1 \% \mathrm{EFL}$ (diet 6 & 120.02 & 2.38 & 1.38 & 23.28 & 13.68 \\
\hline $\mathrm{C}+$ with $2 \% \mathrm{E} \mathrm{FL}$ (diet 7$)$ & 116.52 & 2.40 & 1.36 & 23.26 & 13.43 \\
\hline $\mathrm{C}+$ with $1 \%$ HFM (diet 8 ) & 120.74 & 2.27 & 1.44 & 24.43 & 14.34 \\
\hline $\mathrm{C}$ +with $2 \%$ HFM (diet 9$)$ & 121.93 & 2.65 & 1.24 & 20.05 & 11.79 \\
\hline$C+$ with $1 \%$ TSM (diet 10 ) & 120.22 & 2.50 & 1.31 & 21.51 & 12.87 \\
\hline $\mathrm{C}+$ with $2 \% \mathrm{TSM}$ (dietll) & 120.68 & 2.59 & 1.27 & 20.54 & 12.09 \\
\hline $\mathrm{C}+$ with $1 \% \mathrm{FCM}$ (dietl2) & 119.94 & 2.43 & 1.35 & 22.33 & 13.19 \\
\hline $\mathrm{C}+$ with $2 \% \mathrm{FCM}$ (dietl3) & 117.67 & 2.45 & 1.34 & 22.14 & 13.07 \\
\hline LSD $(\mathrm{P} \in \mathrm{0} .0 \mathrm{~S})^{\prime}$ & Ns & 0.104 & 0.049 & 0.852 & 0.516 \\
\hline
\end{tabular}

*The mean in the same column bearing different superscript are significantly different at $(\mathrm{P} \leq 0.05)$.

Ns $=$ not significant

1- Feed intake (g/fish)

3- Protein efficiency ratio
2- Feed conversion ratio

4- Protein productive value 


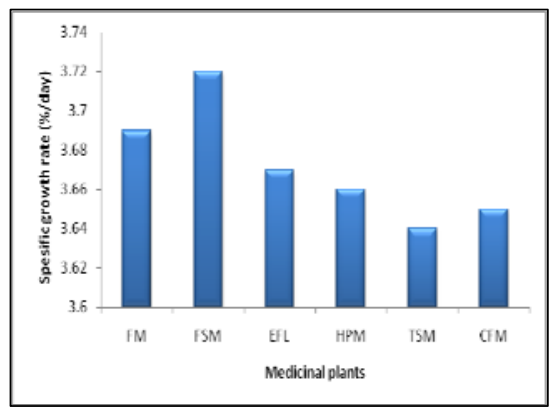

Fig. a

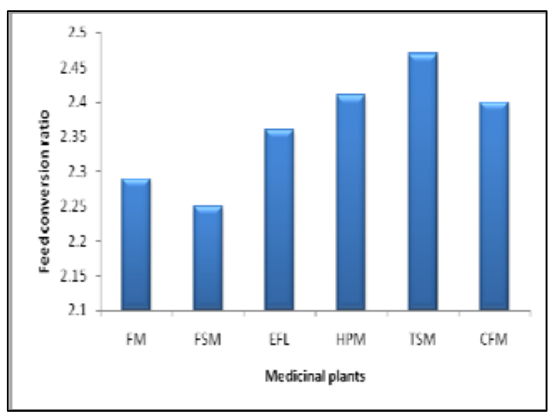

Fig. c

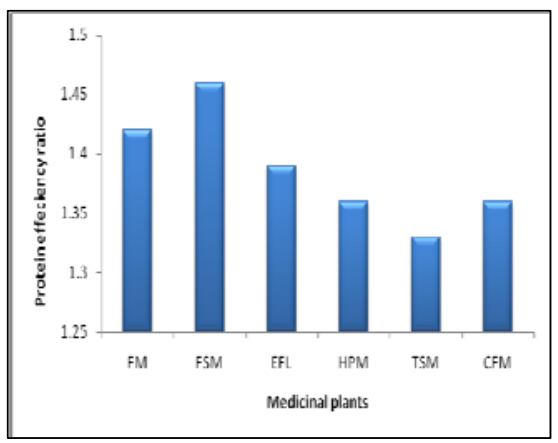

Fig. e

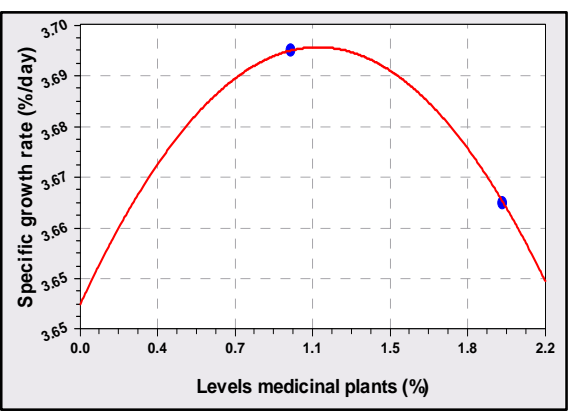

Fig. $b$

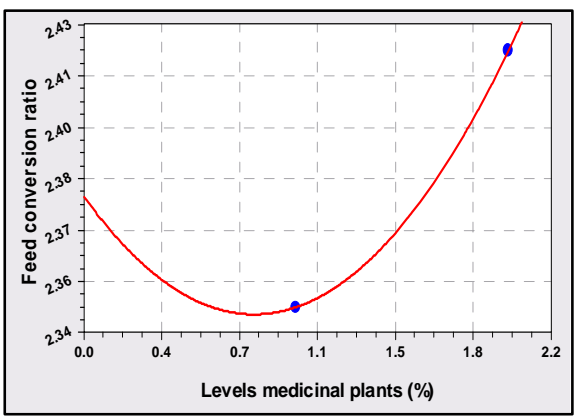

Fig. d

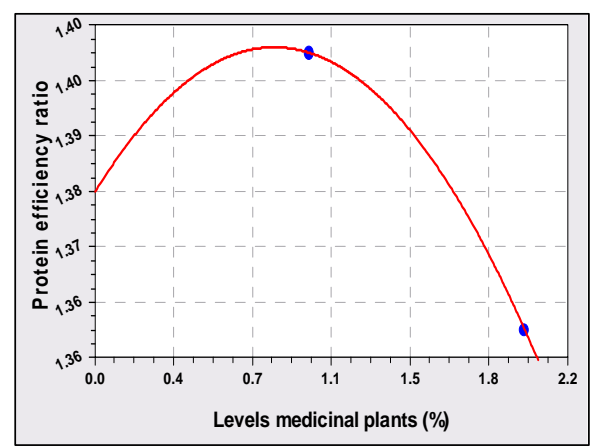

Fig. $f$

Fig. a, b, c, d, e, and f: Effect of some medicinal plants (FM, FSM, EFL, HPM, TSM and CFM) at different levels $(0.00,1.00$ and $2 \%)$ as a feed additive on Specific growth rate, feed conversion ratio and protein efficiency ratio of Nile tilapia $(O$. niloticus) fry. 
The present results disagree with the findings of Salem (2008) who reported that addition of some medicinal plants (six plants) in Nile tilapia diets showed that there are significantly differences $(\mathrm{P} \leq 0.05)$ for feed intake.

Regardless of medicinal plants sources, FCR, PER, PPV \% and EU \% as affected with levels Table (5) and Figs. (e and f) were found to be 2.38, 2.35 and $2.42 ; 1.38,1.40$ and $1.36 ; 22.73,23.43$ and $22.62 \%$ and $12.76,13.84$ and 13.28 $\%$, respectively. The analysis of variance for medicinal plant levels ( MPL) indicate that supplementation level of $1 \%$ revealed significantly $(\mathrm{P} \leq 0.05)$ the best feed and nutrient utilization parameters followed in a significant $(\mathrm{P} \leq 0.05)$ decreasing order by 0.00 and $2.00 \%$ level, respectively .On the other side, the analysis of variance for all medicinal plant levels was not affected significantly $(\mathrm{P} \geq 0.05)$ feed intake. Similar results were reported for medicinal plants in diets for the Nile tilapia (O. niloticus) fingerlings by Abd Elmonem et al. (2002); Sakr (2003); Shalaby et al. (2003); El-Dakar et al., (2004 a and b); On the other side, El-Dakar et al. (2008); Khalil et al. (2009) and Abdelhamid (2010) suggested that the highest feed utilization parameters were recorded by fish fed 2 $\%$ dried basil leaves (DBL) followed by $1 \%$ and $0.5 \%$. On the other hand, the present results disagree with the findings of Salem (2008) who reported that addition of $1 \%$ fenugreek seed as anti-mycotoxins in the Nile tilapia diets decreased the feed utilization parameters.

Concerning the interactions between medicinal plants sources and their levels $(0.00,1.00$ and $2.00 \%)$ the highest feed utilization parameters were obtained by group $1 \%$ FSM (diet No.4), while the lowest was recorded by the group $2 \%$ TSM (diet No.11). This improvement may be due to the effect of their chemical constituents such as antioxidant, antibacterial and antifungal activities on performance stimulation and metabolism (Abdel-Maksoud et al. 1999). In addition, these effective components have a strong stimulating action on bile secretion as well as antispasmodic and anti-inflammatory effects (Murray et al. 1991). Similar results have been reported for medicinal plants in diets for Nile tilapia (O. niloticus) fingerlings by Abdel-Maksoud, et al. (1999); AbdelWahhab et al. (2001); Abd Elmonem et al. (2002); Sakr (2003); El-Dakar et al. (2004a); El-Dakar (2004) and Shalaby et al. (2003) and Shalaby (2004).

\section{C) Body composition}

The whole body composition parameters on dry matter (DM\%) basis, crude protein (CP\%), ether extracts (EE \%) ash and energy content (Kcal/100g) of Nile tilapia (O. niloticus) fry which fed diets containing medicinal plants sources ( FM, FSM, EFL, HPM, TSM and CFM) and their levels are shown in Table (6).

As presented in Table (6) averages of DM \%, CP \%, EE \% and energy content (Kcal $/ 100 \mathrm{~g}$ ) as affected with medicinal plants sources indicate that FSM showed the highest DM \%, CP \%, EE \% and energy content (Kcal /100g) values $(\mathrm{P} \leq 0.05)$ followed in a significant decreasing order by $F M$ and EFL then by HPM and both TSM and CFM, respectively. On the other side, the lowest ash 
content showed in FSM while the highest content was in HPM. These results are in agreement with the results of Abd El-Maksoud et al. (2002); Shalaby et al. (2003).

Table 6: Effect of some medicinal plants (FM, FSM, EFL, HPM, TSM and CFM) at different levels $(0.00,1.00$ and $2 \%)$ as a feed additive on body composition $(\%$ dry weight) of the Nile tilapia (O. niloticus) fingerlings fry.

\begin{tabular}{|c|c|c|c|c|c|}
\hline \multirow{2}{*}{ Treament } & \multirow{2}{*}{$\mathrm{DM} \%$} & \multicolumn{3}{|c|}{ \%onDMbasis } & \multirow{2}{*}{$\begin{array}{l}\text { Brergy catert } \\
\text { (bodiloog) }\end{array}$} \\
\hline & & $\mathrm{CP}$ & $\underline{\mathrm{EE}}$ & Ash & \\
\hline itthe start: & 2387 & 5421 & 20.11 & 2568 & 495.78 \\
\hline \multicolumn{6}{|c|}{ itthe and: } \\
\hline \multicolumn{6}{|c|}{ Medirimalphrts (MP) source } \\
\hline Fropgeti mesl(FM) & $28.0^{2}$ & 5865 & $23.52^{t}$ & 17.85 & $553.07^{t h}$ \\
\hline Feraygeek spoutsmeal(GM) & $28.72^{2}$ & 58.73 & $2355^{\prime}$ & $17.71^{4}$ & $55384^{2}$ \\
\hline Fralyptus fregh lames ( EFL) & $2868^{b}$ & 9836 & $23.47^{h c}$ & $18.17^{c}$ & 55096 \\
\hline Hot pepper mesl(HFM) & $2864^{-1}$ & 5796 & $23.28^{x}$ & 18.7 & 546.94 \\
\hline Tryme meal(TSM) & 28.63 & 598 & 2322 & $1920^{\circ}$ & $544.17^{4}$ \\
\hline Chamomile flowersmeal(CFM) & 2865 & 5796 & $23.45^{1 \mathrm{x}}$ & 18.60 & 548.45 \\
\hline \multicolumn{6}{|c|}{ Level of medirimalplats (LiMT) } \\
\hline $0 \%$ & $28.62^{2}$ & 5805 & 22.78 & $19.78^{2}$ & 54325 \\
\hline $1 \%$ & $28.09^{2}$ & 5832 & $2350^{2}$ & 18.19 & $551 \underbrace{2}$ \\
\hline $2 \%$ & $28.64^{2}$ & 5766 & $2325^{b}$ & $19.10^{2}$ & $545.49^{1}$ \\
\hline \multicolumn{6}{|c|}{$\operatorname{MP} \times \operatorname{LMP}$} \\
\hline cortroldiet,(C) (divt 1) & 2862 & 58.05 & 22.78 & 19.78 & 54325 \\
\hline $\mathrm{C}+\operatorname{did}$ wifh $1 \%$ FM (dikt 2) & 2867 & 58.55 & 23.47 & 1798 & 55202 \\
\hline C + diet wifl $2 \%$ F M (dit 3) & 28.76 & 58.75 & 2359 & 1765 & 55433 \\
\hline C +wiflin $1 \%$ FSM (divt 4) & 28.79 & 58.85 & 2363 & 1752 & 55522 \\
\hline $\mathrm{C}+$ wifh $2 \% \mathrm{FSM}$ (divt 5 ) & 28.71 & 58.70 & 2353 & 17.77 & 553.43 \\
\hline C + wifl $1 \%$ EFL $\quad($ diet 6$)$ & 2868 & 58.60 & 23.47 & 1793 & 55230 \\
\hline $\mathrm{C}+$ wifh $2 \% \mathrm{EFL} \quad(\operatorname{dint} 7)$ & 2868 & 57.84 & 23.44 & 18.72 & 547.73 \\
\hline c +with 1 \% HPM (divt 8 ) & 28.74 & 58.72 & 2357 & 17.71 & 55392 \\
\hline $\mathrm{C}+$ with $2 \%$ HPM (diet 9$)$ & 2850 & 56.90 & 22.76 & 20.74 & 533.75 \\
\hline C + with 1\% TSM (dikt 10) & 2863 & 57.57 & 23.40 & 1903 & 54583 \\
\hline C + with $2 \%$ TSM (dietll) & 2858 & 56.53 & 22.75 & 20.72 & 53382 \\
\hline $\mathrm{C}+$ will $1 \% \mathrm{FCM}$ (dietl2) & 2865 & 57.65 & 23.44 & 1894 & 546.49 \\
\hline $\mathrm{C}+$ wifl $2 \% \mathrm{FCM}$ ( diet13) & 2863 & 57.62 & 24.40 & 1900 & 54599 \\
\hline $\mathrm{LSD}(\mathrm{P}<0.05)$ & 0.082 & 0352 & 0.471 & 0.461 & 4.249 \\
\hline
\end{tabular}

*The mean in the same column bearing different superscript are significantly different at $(\mathrm{P} \leq 0.05)$. **Calculated based on $5.65,9.45$ and $4.12(\mathrm{kcal} / \mathrm{g})$ of protein, lipid and carbohydrate, respectively.

Regardless of medicinal plants sources, DM \%, CP \%, EE \% and energy content (Kcal $/ 100 \mathrm{~g}$ ) as affected with levels (Table 6) were found to be 58.05, 58.32 and $57.66 \% ; 22.78,23.50$ and $23.25 \%$; and 543.25, 551.59 and 545.49 
(kcal/100g), respectively. The analysis of variance for medicinal plant levels (MPL) indicate that supplementation level of $1 \%$ revealed significantly $(\mathrm{P} \leq 0.05)$ the highest CP \%, EE \% and energy content (Kcal $/ 100 \mathrm{~g}$ ) followed in a significant $(\mathrm{P} \leq 0.05)$ decreasing order by 0.00 and $2.00 \%$ level, respectively. On the other side, the analysis of variance for all medicinal plant levels were not significantly $(\mathrm{P} \geq 0.05)$ differed in $\mathrm{DM} \%$. These results are in agreement with the results of Abdel-Maksoud et al., (2002), and Abd Elmonem et al., (2002).

Concerning the interactions between medicinal plants sources and their levels $(0.00,1.00$ and $2.00 \%)$ the highest $\mathrm{CP} \%, \mathrm{EE} \%$ and energy content (Kcal $/ 100 \mathrm{~g}$ ) were obtained by group $1 \%$ FSM (diet No.4), while the lowest was recorded by the group $2 \%$ HPM (diet No.9). These results are in agreement with the results of Abd Elmomem et al. (2002); Sakr (2003); Shalaby et al., 2003); El-Dakar et al. (2004 a and b) and Khalafalla (2009).

\section{D) Blood hematological and biochemical parameters}

Data of the blood hematological and biochemical parameters of the Nile tilapia (O. niloticus) fry which fed diets containing medicinal plants sources (FM, FSM, EFL, HPM, TSM and CFM) and their levels are shown in Table (7).

Average of total plasma protein (g/dl), total plasma lipid (g/dl), hemoglobin concentration $(\mathrm{Hb}) ;(\mathrm{g} / \mathrm{dl})$, Hematocrit $(\mathrm{Ht})(\%)$, aspartate aminotransferase (AST) (U/L), alanine aminotransferase (ALT) (U/L) and uric acid concentrations $(\mathrm{mg} / \mathrm{dl})$ as affected with medicinal plants sources indicate that FSM showed decreases in these parameters $(\mathrm{P} \leq 0.05)$ followed in a significant increasing order by FM and EFL then by HPM and both TSM and CFM, respectively. On the other side, the highest plasma glucose $(\mathrm{mg} / \mathrm{dl})$, and total plasma cholesterol (TPC) $(\mathrm{mg} / \mathrm{dl})$ parameters were recorded by the group FSM, while the lowest was recorder by TSM. These results are in agreement with the results of Abdel-Maksoud et al. (2002), Shalaby et al. (2003); Soltan and El-Lalaity (2008); El-Barbary and Mehrim (2009); Khalil et al. (2009) and Abdelhamid, (2010).

Regardless of medicinal plants sources, blood hematological and biochemical parameters as affected with levels were observed in table (7). The analysis of variance for medicinal plant levels (MPL) indicate that supplementation level of $1 \%$ revealed significant $(\mathrm{P} \leq 0.05)$ the highest total plasma glucose (g/dl), and total plasma cholesterol (TPC) $(\mathrm{mg} / \mathrm{dl})$ followed in a significantly $(\mathrm{P} \leq 0.05) \quad$ decreasing order by 0.00 and $2.00 \%$ level ,respectively. While, the lowest plasma protein $(\mathrm{g} / \mathrm{dl})$, total plasma libid $(\mathrm{g} / \mathrm{dl})$, $\mathrm{Hb}(\mathrm{g} / \mathrm{dl}), \mathrm{Ht}(\%)$, AST (U/L), ALT (U/L) and uric acid concentrations (mg/dl) parameters were recorded by $1 \%$ level.

These results are in agreement with the results of Soltan, A.M. and El-Laithy (2008); El-Barabay and Mehrim (2009); Khalil et al. (2009 a); Farrag et al. (2009) and Abdelhamid (2010), 
Table 7: Effect of some medicinal plants (FM, FSM, EFL, HPM, TSM and CFM) at different levels $(0.00,1.00$ and $2 \%)$ as a feed additive on blood hematological and biochemical parameters of Nile tilapia (O. niloticus) fingerlings fry.

\begin{tabular}{|c|c|c|c|c|c|c|c|c|c|}
\hline Fen & $\begin{array}{l}\text { Phemin } \\
\text { girose } \\
\text { (m gig'di) }\end{array}$ & $\begin{array}{l}\text { plosmia } \\
\text { pottin } \\
\text { (gilli) }\end{array}$ & $\begin{array}{l}\text { plamia } \\
\text { Lipid } \\
\text { (gin) }\end{array}$ & $\begin{array}{c}\mathrm{HB} \\
\text { (g'dil) }\end{array}$ & $\begin{array}{l}\mathrm{HT} \\
(\%)\end{array}$ & $\begin{array}{l}\mathrm{AST} \\
\text { (UL) }\end{array}$ & $\begin{array}{l}\mathrm{ALT}^{2} \\
\text { (UUL) }\end{array}$ & $\begin{array}{c}\mathrm{TPC}^{5} \\
\text { (madelate }\end{array}$ & $\begin{array}{r}\text { Wii } \\
\text { Acid } \\
\text { (melil })\end{array}$ \\
\hline \multicolumn{10}{|c|}{ Medirinalphate (MP) } \\
\hline Fenugreekmeal(FM) & 45.43 & 7.14 & 5.44 & $4.47^{-}$ & $25.31^{5}$ & 36.75 & 2563 & 6381 & 1.77 \\
\hline Frupgeek sprats meal(FSM) & $46.77^{2}$ & 6.97 & 538 & $4.31^{1}$ & $25.27^{2}$ & 36.39 & 2503 & 64.99 & 1.00 \\
\hline Gucalppusfreshleates( $\mathrm{FLL}$ ) & 4409 & 725 & 568 & $4.61^{1}$ & 2565 & 37.19 & 2639 & 6185 & 184 \\
\hline Ht pqper medl(HPM) & 4135 & $7 \overline{63}$ & $\overline{631}$ & $4.81^{-1}$ & $2521^{2}$ & 38.77 & 28.32 & 61.14 & 193 \\
\hline Thqme meal(TSM) & 41.77 & 7.44 & $604^{25}$ & 4.67 & 25.97 & 38.14 & 27.14 & 62.24 & 191 \\
\hline Oham min le flowers meal (CFM) & 4184 & $7.51^{2}$ & $6 \hat{0}^{ \pm 1}$ & $4.71^{11}$ & 2603 & 3828 & 2798 & $61.6 \mathrm{1}^{\mathrm{T}}$ & 190 \\
\hline \multicolumn{10}{|c|}{ Lemels of medicinlphrts(LMP) } \\
\hline $0 \%$ & 41.54 & 7.32 & $6.01^{2}$ & 458 & 2635 & $4086^{2}$ & $2889^{2}$ & 57.52 & 233 \\
\hline $1 \%$ & 44.47 & 722 & $5.57^{\prime}$ & 4.52 & $2560^{\circ}$ & 37.14 & 26.19 & 6299 & 190 \\
\hline $2 \%$ & $4260^{\circ}$ & $7.42^{2}$ & $6.07^{2}$ & 4.67 & 2588 & 3803 & $27.30^{5}$ & 6209 & 199 \\
\hline \multicolumn{10}{|c|}{ MP $\times$ LMP } \\
\hline Control dith $(\mathrm{C})$ & 41.54 & 732 & 601 & 4.98 & 2635 & 4086 & 280 & 5752 & 233 \\
\hline $\mathrm{C}+$ dietwith $1 \% \mathrm{FM}$ (diet 2) & 44.19 & 726 & 5.71 & 458 & 25.45 & 37.14 & 2632 & 6251 & 184 \\
\hline $\mathrm{C}+\operatorname{did}$ wih $2 \% \mathrm{FM}(\operatorname{did} 3)$ & 46.66 & 701 & 5.16 & 435 & 25.17 & 3635 & 2493 & 65.11 & 1.90 \\
\hline $\mathrm{C}+$ with $1 \% \mathrm{FSM} \quad($ diet 4$)$ & 48.16 & 6.79 & 490 & 4.11 & 25.11 & 36.13 & 24.00 & 6537 & $1 \overline{3}$ \\
\hline C +wih $2 \%$ FSM (diet S) & 45.37 & 7.15 & $5 \% 6$ & 451 & 25.42 & 3665 & 2535 & 6381 & $1 \pi$ \\
\hline C + wiih $1 \%$ EFL $\quad($ ditt 6$)$ & 44.56 & 723 & 5.50 & 460 & 2562 & 3692 & 25.42 & 6268 & 182 \\
\hline $\mathrm{C}+\mathrm{wih} 2 \% \mathrm{EFL} \quad($ ditht 7$)$ & 43.03 & 727 & 585 & 462 & 2567 & 37.45 & 2735 & \begin{tabular}{ll|}
6001 \\
\end{tabular} & $1 \%$ \\
\hline C + wifl 1\% HPM (diet 8 ) & 42.19 & 755 & 6.11 & 4.76 & $26.10^{\circ}$ & 38.42 & 2798 & 6160 & 190 \\
\hline $\mathrm{C}+$ wifin $2 \%$ HFM (divt 9$)$ & 40.51 & 770 & 6.52 & 485 & 2631 & 39.11 & 2865 & 6068 & 196 \\
\hline $\mathrm{C}+$ willh $1 \%$ TSM (itat 10) & 45.42 & 705 & 532 & 4.44 & 2537 & 36.44 & 25.11 & 6390 & 1.22 \\
\hline C + + wifl $2 \%$ TSM (dietll) & 38.12 & 783 & 6.75 & 499 & 2657 & 3984 & 20.17 & 605 & 2.10 \\
\hline $\mathrm{C}+$ wifli $1 \% \mathrm{FCM}$ (dikt12) & 42.35 & 7.42 & $5 \%$ & $4 \overline{63}$ & 2595 & 3781 & 2762 & 6185 & 187 \\
\hline $\mathrm{C}+$ wifl $2 \% \mathrm{FCM}$ (dikt13) & 41.32 & 760 & 627 & 4.78 & 26.11 & 38.75 & 2833 & 6137 & 193 \\
\hline LSD $(\mathrm{R}<005)$ & 0.176 & 0.176 & 0265 & 0.133 & 0.176 & 0.274 & 0.274 & 0314 & 0002 \\
\hline
\end{tabular}

*The mean in the same column bearing different superscript are significantly different at $(\mathrm{P} \leq 0.05)$.

**Calculated based on 5.65, 9.45 and $4.12(\mathrm{kcal} / \mathrm{g})$ of protein, lipid and carbohydrate, respectively.

${ }^{1}$ Diet 1 (Control diet), diets 2, 3, 4 containing 0.50, 1.00 and $2.00 \%$ Ginger meal, respectively.

${ }^{2}$ The mean in the same column bearing different superscript are significantly different at $(\mathrm{P} \leq 0.05)$.

${ }^{3} \mathrm{ALT}=$ aspartate aminotransferase

${ }^{4} \mathrm{AST}=$ alanine aminotransferase

${ }^{5} \mathrm{TPC}=$ total plasma cholesterol

Concerning the interactions between medicinal plants sources and their levels $(0.00,1.00$ and $2.00 \%)$ the lowest total plasma protein $(\mathrm{g} / \mathrm{dl})$, total plasma lipid (g/dl), Hb (g/dl), Ht (\%), AST (U/L), ALT (U/L) and uric acid concentrations $(\mathrm{mg} / \mathrm{dl})$ parameters were obtained by group 1\% FSM (diet No.4), while the highest parameters were recorded by the $2 \%$ TSM (diet No.11). These results are in agreement with the results of Abou-Zeid (1998); El-Laithy (2008); 
El-Barbary and Mehrim (2009); Farrag et al. (2009); Soltan, A.M. and Khalil et al. (2009) and Abdelhamid (2010).

\section{CONCLUSION}

Based on the obtained results, the Use of dried fenugreek sprouts (germinated), fenugreek meal, Eucalyptus, fresh hot pepper meal, chamomile flowers and thyme seeds meal at levels of $1 \%$ in tilapia diets have effects a positive on growth performance, feed conversion, nutrient utilization, protein efficiency and physiological parameters in Nile tilapia. Under the experimental conditions, the $1 \%$ level of FSM, FM, EFL, HPM, LMP and TSM was preferable as a feed additive to diets of Nile tilapia.

\section{REFERENCES}

Abdelhamid, H.M.B. (2010). Physiology and nutritional studies on improving growth of Nile tilapia (Oreochromis niloticus) fry using some medicinal plants as a feed additives .MSc. Thesis, University of Kafr El-Sheikh, Egypt.

Abdel-Latif, S. A. A.; El-Yamany, A.T. and Edaly, E. A. F. (2004). Evaluation of using different levels and sources of medicinal herbs in growing Japanese quail diets. Egyptian J. Nutrition and Feeds., 7 (1):69-81.

Abd Elmonem, A.; Shalaby, S. M. M. and El Dakar, A.Y. (2002). Response of red tilapia to different levels of some medicinal plants by-products black seed and roquette seed meal. Proceeding, of the 1st Scientific Conference on Aquaculture 13-15 December 2002, El Arish, Egypt, 247 pp.

Abdel-Maksoud, A.; Aboul-Fotouh, G.E.; Allam, S. M. and Zied, R. M. A. (1999). Effect of marjoram leaves (Majorana hortensis L. [Origanum majorana]) as a feed additive on the performance of Nile tilapia (Oreochromis niloticus) fingerlings. Egyptian Journal of Nutrition and Feeds. 2 (1): 39-47.

Abdel-Maksoud, A.M.S., Aboul-Fotoh, G.E., Allam, S.M.\&Abou-Zied, R.M. (2002). The response of Nile tilapia to animal protein free diets supplemented with some free amino acids and some medicinal plants. $1^{\text {st }}$ Conference in Aquaculture. Egyptian Aquaculture Society, El-Arish, Egypt, pp. 233-260.

Abdel-Wahhab, A.W.M. (2001). Effect of dietary protein source and addition of some medicinal plants on growth performance of Nile tilapia. Ph.D., Faculty of Agriculture, Cairo University, Fayoum Branch. 
Abou-Zeid, R. M. (1998). Evaluation of some medicinal ploants as a feed additive in diet of Nile tilapia (Oreochromis niloticus). M.Sc. Thesis, Faculty of Agriculture, El-Fayom, Cairo University, Egypt.

Al-Absawy, A. N. M. (2010) Nutritional requirements for Nile tilapia, Oreochromis niloticus, cultured in El-Max research station with special references to their growth and feeding habits. M. Sc. Thesis, Faculty of Science, Al-Azhar University, Cairo, Egypt

AOAC (Association of Official Analytical Chemists). Official methods of analysis (2000). Arlington Virginia. three Borlongan IG, Coloso RM, Requirements of juvenile milkfish (Chanos chanos Forsskai) for essential amino acids. J. Nutr. 1993; 123: 125-132.

APHA (American Public Health Association). (1992). Standard methods for the examination of water and wastewater. 18th ed. APHA, Washington, DC.

Billaud C and J. Adrian (2001). Fenugreek: Composition, nutritional value and physiological properties. Sciences-des-ailments, 21(1):3-26.

Castell, J. D. and Tiewes K. (1980). Report of the EIFAC, IUNS and ICES working group on the standardization of methodology in fish research, Hamburg, FRG, 21-23 March 1979. IFAC tech. Pap., 3 (24):

Dixit, P.; Ghaskadbi, S.; Mohan, H. and Devasagayam, T. P. (2005). Antioxidant properties of germinated fenugreek seeds. Phytother Res. 2005 Nov; 19(11): 977-83.

El-Barabay, M. I. and Mehrim, A. I. (2009). Protective effect of antioxidant medicinal herbs ,Rosemary and Parsley, on sub acute aflatoxicosis in Nile Tilapia, Oreochromis niloticus. Journal of Fisheries and Aquatic Science, 4(4):178-190.

El-Dakar, A.Y.; Hassanein, G. D. I.; Gad, S. S. and Sakr, S. E. (2004a). Use of medical and aromatic plants in fish diets: 1- Effect of dried marjoram leaves on performance of hybrid tilapia, Oreochromis niloticus $x$ Oreochromis auraus, fingerlings. J. Egypt. Acad. Soc. Environ. Dev. B (Aquaculture), 5 (1): 67-83.

El-Dakar, A.Y.; Shalaby, S. M.; Abdel-Monem, A. I. and Wahby, O. M. (2004b). Enhancement of performance using fennel seeds meal as feed additive for Nile tilapia, reochromis niloticus. J. Egypt. Acad. Soc. Environ. Dev. B (Aquaculture). 5: 43-67. 
El-Dakar, A.Y. (2004). Growth response of hybrid tilapia, Oreochromis niloticus $\mathrm{x}$ Oreochromis auraus, fingerlings to diets supplemented with different levels of caraway seeds. Mansoura University Journal of Agricultural Sciences, 29: 6083-6094.

El-Dakar, A. Y.; Shalaby, S. M. and Saoud, I. P. (2007). Assessing the use of dietary probiotic/prebiotic as an enhancer of spinefoot rabbitfish Singanus rivulatus survival and growth. Aquacult. Nut., 13:407-412.

El-Dakar, A. Y.; Hassanien, G. D.; Gad, S. S. and Sakri, S. E. (2008). Use of Dried Basil Leaves as a Feeding Attractant for Hybrid Tilapia, Oreochromis niloticus $X$ Oreochromis aureus, Fingerlings. Mediterranean Aquaculture Journal, 1(1): 35- 44.

Ellefson, R. D. and Caraway, W. T. (1976). Fundamentals of clinical chemistry. Ed, Tietz NW., P 506.

Farrag, F. H.; Khalil F. F. and Mehrim, A. I. (2009). Reduction of lead oxide toxicity by using bentonite in mono-sex Nile Tilapia, Oreochromis niloticus diets. Abbassa international journal for Aquaculture. ISSN 16877683, special issue for Global Fisheries Research Conference, Cairo international Convention Center, 24-26 October 2009, pp 429-451.

Harada, K. (1990). Attraction activities of spices for oriental weatherfish and yellowtail. Nippon Suisan Gakkaishi. 56 (12): 2029-2033.

Gornall, A. G.; Bardawill, G. J. and Parid, M. M. (1949). Method of protein in serum blood. J. Biol. Chem., pp.177-751.

NRC, National Research Council (1993). Nutrition requirements of fish. National Academic Press, Washington, DC.

Khalafalla, M. E. (2009). Utilization of Some Medical Plants as Feed Additives for Nile Tilapia, Oreochromis niloticus, feeds. Mediterranean Aquacult. J., 2(2): 10-19.

Khalil, F. F.; Farrag, F. H. and Mehrim, A. I. (2009). Using Marjorana hortensis against contamination of mono-sex Nile Tilapia, Oreochromis niloticus diets by lead oxide. Abbassa international journal for Aquaculture. ISSN 1687-7683, special issue for Global Fisheries Research Conference, Cairo international Convention Center, 24-26 October 2009, pp. 407-428. 
Mohamed, A. H.; El-Saidy, B. E. and El-Seidy, I. A. (2003). Influence of some medicinal plants supplementation: 1- On digestibility, nutritive value, rumen fermentation and some blood biochemical parameters in sheep. Egyptian J. Nut. and Feeds., 6 (2): 139-150.

Murray, R. K.; Granner, D. K.; Mayes, P. A. and Rodwell, V. W. (1991). The text book of Harper's biochemistry. $22^{\text {nd }}$ ed. Appleton and Large, Los Altos, California

Recker,W. E. (1975). Computation and interpretation of biological statistics of fish population. Fish Res. Borard Can. Bull.,191.

Sakr, S. E. (2003). Studies on the feeding attractants for fish. M.Sc., Faculty of Environmental Science, Suez-Canal University. Kwon.

Salem, M. E. M. (2008). Studies on some medicinal plants as anti-mycotoxins in fish diets. M. Sc. Thesis, Faculty Agriculture, Kafrelsheikh university, Egypt

Schultz, A. (1984). Uric acid. Clin. Chem, The C.V. Mosby Co. St. Louis. Toronto. Princeton, pp.1261-1266.

Shalaby, S. M. (2004). Response of Nile tilapia, Oreochromis niloticus, fingerlings to diets supplemented with different levels of fenugreek seeds (Hulba). Mansoura University Journal of Agricultural Sciences. 29 (5): 2231-2242.

Shalaby, S. M.; Abdel-Monem, A. I. and El-Dakar, A. Y. (2003). Enhancement of growth performance, feed and nutrient utilization of Nile tilapia (Oreochromis niloticus), using of licorice roots (Erksous) as a feed attractive. .Egypt. Acad. Soc. Environ. Dev. B (Aquaculture). 4: 119-142.

Soltan, A. M. and El-Laithy, S. M. (2008). Effect of pribiotics and some spices feed additives on the performance and behavior of the Nile tilapia, Egypt. J. Aquat. Biol. and Fish, 12: 63-80.

SAS (1997). SAS/STAT Guide for personal computer. SAS Inst. Cary, N.C. (ISBN: 3-540-65014-8.Statistical Package for the Social Sciences, SPSS, USA.

Steel, R. G. and Torrie, J. H. (1980). Principles and procedures of statistics. Mc Graw Hill Book Co., New York. 
Tonsy H. D.; Faiza A.; Salama, S.; Mahmoud, H.; El-Kholy, Kh. F. and M. N. Ali. (2010). Efficiency of using low plant protein diets containing some feed additives on growth performance and body composition of Nile tilapia (Oreochromis niloticus) FRY. Egyptian J. Nutrition and Feeds., 13(3): 607-621.

Varley, V. (1976). Paractical Clinical Biochemistry. $4^{\text {th }}$ Edition, Newdelhi, India Etal. 